\title{
POCZĄTKI PARAFII PW. NAJŚWIECTSZEGO SERCA PANA JEZUSA W BRZEŚCIU NA GRAJEWSKIM PRZEDMIEŚCIU
}

Brześć nad Bugiem (białoruskie Брэст, Берасьце) to polskie miasto kresowe na Polesiu, nazywane potocznie Brześciem Litewskim. Wzmiankowane jest już w XI-wiecznych kronikach historycznych. Od XII wieku Brześć należał do Polski. Po zawarciu unii brzeskiej miasto było stolicą województwa brzesko-litewskiego. W wyniku trzeciego rozbioru Polski, znalazło się w zaborze rosyjskim. Po pierwszej wojnie światowej Brześć powrócił (1919) w granice II Rzeczypospolitej. W sierpniu 1921 roku przeniesiono do niego stolicę województwa poleskiego z Pińska. Od listopada 1923 roku Brześć Litewski został przemianowany na Brześć nad Bugiem. Mieściła się tu siedziba powiatu brzeskiego i sztab Wojskowego Okręgu Korpusu Brześć Litewski¹. W latach międzywojennych Brześć nad Bugiem zarówno obszarem jak i ilością mieszkańców był największym miastem w diecezji pińskiej². Po II wojnie światowej Brześć pozostał w granicach ZSRR

* Ks. Waldemar Witold Żurek SDB - dr hab. historii Kościoła, prof. KUL, dyrektor Ośrodka Archiwów Bibliotek i Muzeów Kościelnych, e-mail: zurek@kul.pl

${ }^{1}$ Minister Spraw Wojskowych dnia 1 VIII 1921 roku utworzył Wojskowy Okręg Korpusu Brześć Litewski. W 1922 roku obszar Polski został podzielono na dziewięć Okręgów Korpusów, wśród których Okręg nr IX otrzymał nazwę „Poleskiego”. W jego skład wchodziły oddziały z województwa białostockiego i nowogródzkiego, północnej części lubelskiego i dużej części województwa poleskiego. W. Bieszanow, Twierdza Brzeska, Warszawa 2012, s. 117.

${ }^{2}$ Biskupstwo łacińskie w Pińsku na Polesiu utworzyła cesarzowa Katarzyna II ukazem z dnia 27 IX 1795 roku na terytorium diecezji łuckiej, które zagarnęła podczas drugiego i trzeciego rozbioru Polski. Diecezja ze stolicą w Pińsku nigdy nie otrzymała sankcji kanonicznej Stolicy Apostolskiej. W 1798 roku, w ramach reorganizacji kościoła łacińskiego na tzw. ziemiach zabranych, diecezja została skasowana i przywrócono diecezję łucką. Pińsk znalazł się wówczas w granicach nowo utworzonej diecezji mińskiej. Traktat ryski z 1921 roku podzielił terytorium diecezji mińskiej między Polskę (53 parafie i 73 kaplice publiczne) i ZSRR (55 parafii). Rezydencją biskupa mińskiego Zygmunta Łozińskiego był wówczas Nowogródek. Katolicy polskiej części diecezji mińskiej stanowili mniejszość etniczną. Konkordat z 10 II 1925 roku stworzył nową diecezję ze stolicą w Pińsku, erygowaną bullą Piusa XI z dnia 28 X 1925 roku. Obejmowała ona część diecezji mińskiej w politycznych granicach II Rzeczypospolitej (9 dekanatów - 53 parafie, z diecezji wileńskiej 6 de- 
(Białoruskiej Republiki Socjalistycznej). Został centrum administracyjnym obwodu (województwa) brzeskiego w zachodniej części Białorusi oraz siedzibą rejonu (powiatu) brzeskiego. Od 1991 roku miasto znajduje się w granicach Republiki Białoruś. Do dziś stanowi ośrodek kultury polskiej na Białorusi. Pod względem administracji kościelnej Brześć należy do diecezji pińskiej, jednej z czterech diecezji obrządku łacińskiego wchodzącej w skład metropolii mińsko-mohylewskiej.

$* * *$

\section{Obywatelski Komitet Budowy Kościoła w Brześciu nad Bugiem}

Zgodnie z ustawodawstwem kościelnym powstający Społeczny Komitet Budowy Kościoła winien być powołany zgodnie z określonymi procedurami. Powinien zawierać imiona i nazwiska jego członków z zaznaczeniem członków czynnych, wskazanie jego zarządu: przewodniczący, zastępcy, sekretarz i skarbnik oraz skład komisji rewizyjnej. Tak ukonstytuowany skład Społecznego Komitetu Obywatelskiego budowy jakiegokolwiek kościoła winien być przedstawiony Kurii Diecezjalnej do zatwierdzenia, które potwierdzał biskup ordynariusz. Bez powyższej procedury powoływany w związku z budową jakiegokolwiek kościoła parafialnego komitet nie mógł prawnie działać. Za odpowiedni czasookres działalności Komitetu, jego zarząd przesyłał okresowe sprawozdania do Kurii Biskupiej celem jego zatwierdzenia, w tym także sprawozdanie finansowe, sporządzone przez sekcję finansową Komitetu³.

Powyższą procedurę zachowano planując budowę świątyni parafialnej na Przedmieściu Grajewskim w Brześciu nad Bugiem (tzw. Grajewka), w diecezji pińskiej. W piśmie z dnia 16 VII 1930 roku dziekan brzeski i proboszcz parafii Podwyższenia Krzyża Świętego ks. Józef Moniuszko ${ }^{4}$ przesłał do Diecezjalnej Rady Gospodarczej Kurii Pińskiej listę powołanego Społecznego Komitetu Budowy Kościoła na Przedmieściu Grajewskim z prośbą o jego zatwierdzenie. Jego skład stanowili: ksiądz proboszcz i dziekan brzeski ks. Jan Moniuszko - prezes,

kanatów i 6 parafii - łącznie 67 parafii). Pierwszym biskupem diecezji pińskiej został biskup miński Zygmunt Łoziński. Diecezja należała do metropolii wileńskiej. Po II wojnie większość terytorium diecezji pińskiej pozostało w granicach Białoruskiej SRR. Od 1950 roku terenem diecezji pińskiej pozostającej w granicach PRL zarządzał administrator apostolski w Drohiczynie. Unikano wówczas dla tej części diecezji przedwojennej nazwy diecezja pińska, a zamiast tego używano określenia diecezja w Drohiczynie n. Bugiem. W 1991 roku z pozostałej przy Polsce tej części diecezji została erygowana diecezja drohiczyńska. B. Kumor, Granice metropolii i diecezji polskich (968-1939) cd., „Archiwa Biblioteki i Muzea Kościelne” 22 (1971) s. 335-338.

${ }^{3}$ ADD, Zespół Archiwum Parafii Brześć, Sygn. XII/V - „Varia” 1931-1935, Kuria Biskupia -Rada Diecezjalna Gospodarcza (RDG) do proboszcza kościoła Najświętszego Serca Pana Jezusa z 10 III 1932 (L. 270/R.G.), z 27 III 1936 (L. 1259/36).

${ }^{4}$ Ks. Moniuszko Józef - kapłan diecezji pińskiej, doktor filozofii, ur. w 1887 roku, wyświęcony w 1913 roku, pełnił obowiązki pierwszego proboszcza parafii Najświętszego Serca Pana Jezusa w Brześciu n/ Bugiem, od 1938 roku był prefektem gimnazjum kupieckiego i kapelan szpitala powiatowego. Spis kościołów i duchowieństwa diecezji pińskiej w R. P. 1939, Pińsk 1939, s. 18, 40. 
Franciszek Czernek, Aleksander Giecewicz, Wacław Haczyński, Jan Kawęcki, Franciszek Niedźwiedzki, Aleksander Rodziewicz, Antoni Rodziewicz, Kazimierz Sawukinas, Józef Siemaszko, Piotr Suszyński. Diecezjalna Rada Gospodarcza Pińskiej Kurii Biskupiej na posiedzeniu w dniu 24 lipca tego roku powzięła uchwałę i zatwierdziła listę członków przedstawionego Społecznego Komitetu Budowy Kościoła nowego w tym mieście ${ }^{5}$.

Dnia 4 IX 1931 roku Diecezjalna Rada Gospodarcza Kurii Pińskiej zatwierdziła nowy, nieco zmieniony skład Komitetu w osobach: inż. Franciszek Czarnocki, Mieczysław Fiedorowicz (zawiadowca stacji kolejowej Brześć Centralny), inżynier Mieczysław Gordziałkowski, Paweł Kulikowski, Leon Paszkiewicz, inżynier Jan Radzikowski, inżynier Ludwik Soroka, Bolesław Szperling (sekretarz magistratu Brześcia), inżynier Aleksander Tyszka, Franciszek Usajewicz (zastępca starosty powiatu brzeskiego), Mieczysław Wężyk (prezydent miasta Brześcia), inżynier Władysław Żeleźniak ${ }^{6}$.

Z upływem czasu skład Komitetu ulegał zmianom z przyczyn niezależnych od jego członków, chociażby w związku ze zmianą zajmowanego stanowiska zawodowego, zmiany miejsca zamieszkania czy pracy i podejmowanych nowych obowiązków. Dnia 5 III 1932 roku proboszcz parafii na Grajewskim Przedmieściu przesłał do zatwierdzenia Rady Gospodarczej Kurii Diecezjalnej w Pińsku kolejny wykaz uzupełnionego składu Komitetu Budowy Kościoła. Liczył on 23 osoby. Z jego członków wyłoniono komisję rewizyjną, sekcję finansową i komitet wykonawczy. Zasadniczy człon stanowił komitet wykonawczy: przewodniczący, I. wice-przewodniczący, II. wice-przewodniczący, skarbnik i sekretarz, który stanowił zarząd Komitetu Obywatelskiego. Dnia 7 marca tego roku otrzymał on zatwierdzenie Diecezjalnej Rady Gospodarczej Kurii Biskupiej Pińskiej, podpisany przez prałata ks. Nikodema Tarasiewicza - wice-prezesa Rady?

${ }^{5}$ ADD, Zespół Archiwum Parafii Brześć, Sygn. XII/V, Wiceprezes Diecezjalnej Rady Gospodarczej do dziekana brzeskiego z 30 VII 1930 (L. 546/RG) i załącznik z listą z 30 VII 1930 (L. 546/ $\mathrm{RG})$.

${ }^{6}$ ADD, Zespół Archiwum Parafii Brześć, Sygn. XII/V, Diecezjalna Rada Gospodarcza w Pińsku do dziekana brzeskiego z 4 IX 1931 (L. 805); Ks. Jan Moniuszko do Diecezjalnej Rady Gospodarczej w Pińsku z 5 III 1932 (L. 14).

${ }^{7}$ Ks. Tarasiewicz Nikodem (1868-1955) - kapłan diecezji pińskiej, prałat, dziekan wołkowyski (1919), dziekan stołpecki (1935-1938), w latach 1920-1929 pracował w Brześciu, wiceprezes Rady Gospodarczej Kurii Biskupiej Pińskiej (1932), wiceoficjał Sądu Biskupiego w Pińsku (1928-1940), administrator parafii Humienowszczyzna-Rendwidowo (w stanie organizacji - 1935), dziekan Kapituły Katedralnej Pińskiej, Kanonik Honorowy Wileńskiej Kapituły Katedralnej. Spis kościołów i duchowieństwa diecezji pińskiej w R. P. 1935, Pińsk 1935, s. 25, 169; Spis kościołów i duchowieństwa diecezji pińskiej w R. P. 1937, Pińsk 1937, s. 18-23. 
Tab.1. Społeczny Komitet Budowy Kościoła w Brześciu w marcu 1932 roku.

\begin{tabular}{|c|c|c|}
\hline \multicolumn{3}{|c|}{ Komitet Wykonawczy } \\
\hline Przewodniczący & Skarbnik & Sekretarz \\
\hline ks. Józef Moniuszko - proboszcz & \multirow{3}{*}{$\begin{array}{l}\text { Wacław Chaczyński } \\
\text { (Haczyński) }\end{array}$} & \multirow{3}{*}{$\begin{array}{l}\text { Aleksander } \\
\text { Rodziewicz }\end{array}$} \\
\hline Franciszek Czarnecki - I. wice-przewodniczący & & \\
\hline Piotr Suszyński - II. wice-przewodniczący & & \\
\hline \multicolumn{3}{|l|}{ Komisja Rewizyjna } \\
\hline \multicolumn{3}{|c|}{ Leon Muchowicz, dr Marian Sawicki, Ludwik Soroka, Bolesław Szperling } \\
\hline \multicolumn{3}{|l|}{ Sekcja Finansowa } \\
\hline \multicolumn{3}{|c|}{$\begin{array}{l}\text { Franciszek Czernek, Mieczysław Fedorowicz, Klemans Gajżewski, Stanisław Murawski, Mikoła } \\
\text { Sawukinas, Józef Siemaszko, Franciszek Usajewicz, Władysław Żeleźniak }\end{array}$} \\
\hline
\end{tabular}

Członkami Społecznego Komitetu Budowy Kościoła byli inżynierowie: Franciszek Czarnocki, Mieczysław Gordziałkowski, Paweł Kulikowski, Jan Radzikowski, Ludwik Soroka, Bolesław Szperling, Aleksander Tyszka, Franciszek Usajewicz, Mieczysław Wężyk, Władysław Żeleźniak oraz panowie: Franciszek Czernek, Jan Kawęcki, Franciszek Niedźwiecki, Antoni Rodziewicz, Piotr Suszczyński ${ }^{8}$.

W odpowiedzi na pismo wiceprzewodniczącego Diecezjalnej Rady Gospodarczej Kurii Biskupiej w Pińsku z dnia 10 III 1932 roku aby powyższą listę Komitetu uzupełnić przez dodanie do jego składu inżynierów zaangażowanych w budowę przyszłego kościoła, przewodniczący Komitetu ks. kanonik Moniuszko dołączył następujące osoby: inż. Klemens Gajżewski, inż. Józef Barański, inż. Stanisław Murawski oraz Marian Sawicki i Leon Muchowicz'.

Sekcja finansowa Komitetu Budowy Kościoła na Grajewskim Przedmieściu przesłała do Kurii Diecezjalnej w Pińsku sprawozdanie za okres od 1 V 1934 do 1 III 1936 roku. Nie znalazłszy w przedstawionym sprawozdaniu nieprawidłowości Diecezjalna Rada Gospodarcza kurii przesłała na ręce proboszcza ks. kan. Łucjana Żołądkowskiego ${ }^{10}$ pismo z informacją, że treść sprawozdania została przyjęta,

${ }^{8}$ ADD, Zespół Archiwum Parafii Brześć, Sygn. XII/V, Ks. Józef Moniuszko do Diecezjalnej Rady Gospodarczej w Pińsku z 5 III 1932 (L. 14).

${ }^{9}$ ADD, Zespół Archiwum Parafii Brześć, Sygn. XII/V, Proboszcz i przewodniczący Komitetu do Kurii Diecezjalnej w Pińsku z 5 III 1932 nr 14; Wiceprzewodniczący DRG ks. N. Tarasiewicz do proboszcza kościoła NSP Jezusa w Brześciu z dnia 10 III 1932 L. 270/R. G. (Pińsk).

${ }^{10}$ Żołądkowski Lucjan (1883-1946) - kapłan diecezji mińskiej, następnie pińskiej, kanonik honorowy Kapituły Katedralnej Mińskiej. Święcenia kapłańskie przyjął dnia 25 I 1909 roku w Petersburgu. Od 1910 roku pracował jako wikariusz przy Złotej Górce w Mińsku, od następnego roku jako administrator parafii św. Szymona i Heleny w Mińsku,w latach 1924-1933 był administratorem, następnie proboszczem i budowniczym kościoła pw. Podwyższenia Krzyża Świętego w Baranowiczach i dziekanem baranowickim. W latach 1933-1937 pracował jako proboszcz parafii Najświętszego Serca Pana Jezusa w Brześciu na Grajewskim Przedmieściu, pełnił funkcję dziekana brzeskiego oraz rektora kościoła filialnego w Skokach. W latach 1937-1938 był proboszczem kościoła Podwyższenia Krzyża Świętego w Brześciu nad Bugiem i dziekanem brzeskim. Od 1938 roku przejął funkcję kierownika Wydziału Metrykalnego Pińskiej Kurii Diecezjalnej. W czasie leczenia sanatoryjnego proboszcza z Peliszcz ks. Wacława Tumiłowicza w 1940 roku, zastępował go ks. Żołądkowski, który pozostał na stałe w Peliszczach. Po wojnie pozostał w tej parafii, położonej w 
do wiadomości oraz wyraża najwyższe uznanie i podziękowanie za wytężoną $\mathrm{i}$ skuteczną pracę. Z tej okazji biskup piński Kazimierz Bukraba ${ }^{11}$ udzielił członkom sekcji finansowej Komitetu pasterskiego błogosławieństwa ${ }^{12}$.

\section{Erekcja parafii i jej uposażenie}

Uznając potrzebę utworzenia kolejnego ośrodka duszpasterskiego w Brześciu, biskup piński Zygmunt Stanisław Łoziński ${ }^{13}$ erygował kanonicznie dnia 2 I 1932 roku parafię w Brześciu nad Bugiem, na Grajewskim Przedmieściu, przy ulicy Mieszczańskiej ${ }^{14}$. W ten sposób powstała druga parafia rzymskokatolicka w tym mieście, po parafii Podwyższenia Świętego Krzyża ${ }^{15}$, ufundowanej w XV

dekanacie i obwodzie brzeskim, obsługiwał także parafię Kamieniecką. Zmarł na raka w Brześciu i pochowany został na cmentarzu katolickim przy ul. Puszkińskiej (dawniej 3 Maja) przy kaplicy. L. Mihailik, Kościół katolicki na Grodzieńszczyźnie 1939-1956, Warszawa 2008, s. 311; Spis Kościołów i Duchowieństwa Diecezji Pińskiej, Pińsk 1936, s. 65,69 oraz z lat 1938 i 1939; K. Wojciechowski, Cmentarz katolicki w Brześciu, „Niedziela” nr 45 (737) z 4 XI 2012, s. 7.

${ }^{11}$ Bp Bukraba Kazimierz (1885-1946) - ordynariusz piński, następca biskupa Zygmunta Łozińskiego. Urodził się w Grodnie. Teologiczne studia seminaryjne rozpoczął w 1904 roku Petersburgu, uzupełnił w Innsbrucku. Święcenia kapłańskie przyjął dnia 2 II 1909 roku w Krakowie z rąk bpa Anatola Nowaka. Pracował w duszpasterstwie w Mińsku, Pińsku, od 1919 roku był proboszczem i dziekanem w Nowogródku, od 1928 roku dziekanem i proboszczem w Brześciu nad Bugiem. W 1932 roku mianowany został przez papieża Piusa XI biskupem pińskim. Ogłosił w 1934 roku statuty synodu diecezjalnego. Rozbudował sieć parafialną diecezji, do pracy w diecezji sprowadził zakony (jezuitów, marianów, werbistów, siostry urszulanki szare). W 1939 roku wyjechał z Pińska, przez Lwów do Warszawy. A. Petrani, Bukraba Kazimierz, w: Encyklopedia Katolicka (dalej: EK), t. 2 Lublin 1985, kol. 1189-1190.

${ }^{12}$ ADD, Zespół Archiwum Parafii Brześć, Sygn. XII/V, Pismo wikariusza generalnego do ks. kan. Lucjana Żołądkowskiego z 27 III 1936 r.- Pińsk (L. 1259/36).

${ }^{13}$ Bp Łoziński Zygmunt Stanisław (1870-1932) - pierwszy ordynariusz erygowanej w 1925 roku diecezji pińskiej, teolog, sługa Boży. Był absolwentem Akademii Duchownej w Petersburgu. W 1895 roku przyjął święcenia kapłańskie. Był wykładowcą w seminarium duchownym w Pińsku (Pismo św., homiletyka). Po powrocie z banicji w klasztorze karnym w Agłomie (Łotwa) pracował w duszpasterstwie. Za przyjmowanie unitów do Kościoła katolickiego został usunięty z Mińska. Podjął wykłady z Pisma św. i języka hebrajskiego w Akademii Duchownej w Petersburgu. Studiował biblistykę w Monachium, Rzymie, Jerozolimie i ponownie w Rzymie. W 1917 roku został ordynariuszem reaktywowanej diecezji mińskiej. Sakrę biskupią przyjął w 1918 roku w Warszawie. Po proklamowaniu w 1919 roku Białoruskiej SRR został aresztowany i przewieziony do Moskwy, zwolniony na mocy traktatu ryskiego z 1921 roku. Następnie udał się do Nowogródka w celu organizowania życia religijnego w polskiej części diecezji mińskiej. W 1925 roku został pierwszym ordynariuszem diecezji pińskiej. Zmarł w opinii świętości. Jego proces beatyfikacyjny rozpoczął się w 1957 roku w Rzymie. J. Misiurek, Loziński Zygmunt, w: EK, t. 11, Lublin 2006, kol. 554-555.

${ }^{14}$ ADD, Zespół Archiwum Parafii Brześć, Sygn. XII/V, Dekret erekcyjny parafii w Brześciu Grajewskie Przedmieście z 2 I 1932 (Num. 46/32).

${ }^{15}$ Parafia rzymskokatolicka pw. Podwyższenia Świętego Krzyża utworzona została na początku XV wieku w granicach diecezji łuckiej, przy drewnianym kościele wybudowanym z fundacji króla Władysława Jagiełły i dodatkowo uposażonym przez księcia litewskiego Witolda. W 1805 roku drewniany kościół doszczętnie spłonął, a parafię przeniesiono do kościoła pojezuickiego, od 1808 roku do kościoła bernardynów. Od 1831 roku świątynią parafialną był kościół murowany na 
wieku. Jej pierwszym proboszczem został ks. Józef Moniuszko, dotychczasowy proboszcz parafii Stołpce, który otrzymał nominację do Brześcia dnia 2 I 1932 roku, zgodnie z kanonem 1406, paragraf 1, numer 7 Kodeksu Prawa Kanonicznego. Stosownie do próśb tamtejszych wiernych parafia otrzymała tytuł i wezwanie Najświętszego Serca Pana Jezusa. Na początku liczyła około 4.000 wiernych ${ }^{16}$.

Prawie rok wcześniej proboszcz parafii rzymskokatolickiej pw. Podwyższenia Świętego Krzyża ks. Józef Moniuszko na mocy upoważnienia ordynariusza z dnia 23 II 1931 roku (Nr rep. 480) został upoważniony do podpisania z dyrekcją Polskich Kolei Państwowych w Wilnie umowy na dzierżawę budynku kolejowego w Brześciu przy ulicy Mieszczańskiej nr 18, na dwanaście lat, z przeznaczeniem na tymczasową kaplicę dla mającej powstać parafii ${ }^{17}$. Należność za dzierżawę budynku kolejowego na stacji Brześć III wynosiła 100 złotych rocznie. Taką kwotę ustaliły zainteresowane strony: kościelna i kolejowa za okres od 9 IX 1932 do 9 IX 1933. Najprawdopodobniej taka kwota została utrzymana w późniejszych la$\operatorname{tach}^{18}$. W wydzierżawionym budynku kolejowym staraniem pełniącego obowiązki proboszcza na Grajewce ks. Józefa Moniuszko, otwarto tymczasową kaplicę publiczną, którą poświęcono w 1932 roku.

Wydzielona w 1932 roku z parafii pw. Podwyższenia Świętego Krzyża, nowa

przedmieściu Brześcia, który po pożarze w 1851 roku, został gruntownie przebudowany i konsekrowany w 1856 roku przez biskupa wileńskiego Wacława Żylińskiego. W jołtarzu bocznej nawy kościoła umieszczono XVI-wieczny cudowny obraz Matki Bożej Brzeskiej - Matki-Zbawicielki, z dawnego kościoła bernardynek w Brześciu. Obraz ten jest kopią obrazu z rzymskiej bazyliki Matki Bożej Większej, przekazaną w Rzymie kasztelanowi brzeskiemu Adamowi Pociejowi przez papieża Klemensa VIII (1592-1605). Dnia 30 VII 1939 roku bp Kazimierz Bukraba poświęcił kamień węgielny pod przedłużenie tej świątyni. Po zalaniu fundamentów rozbudowę jego przerwał wybuch drugiej wojny światowej. Dnia 15 I 1948 roku kościół Podwyższenia Świętego Krzyża w Brześciu przy ul. Lenina 34 został zamknięty przez władze komunistyczne, a od 1951 roku mieściło się w nim Muzeum Krajoznawcze. Z wyposażenia kościoła nie ocalało nic, z wyjątkiem cudownego obrazu ukrytego przez wiernych. Dnia 12 VIII 1990 roku, po 42 latach, została odprawiona po raz pierwszy w tym kościele Msza św., a od Nowego Roku 1991 roku świątynia została zwrócona katolikom. Jej konsekracji dnia 28 VIII 1992 roku dokonał abp Kazimierz Świątek. Do odremontowanej świątyni powrócił na swoje wcześniejsze miejsce cudowny wizerunek Matki Bożej, który dnia 30 VI 1996 roku został ukoronowany papieską koroną. ADD, Zespół: Archiwum Parafii Brześć, Sygn. XI/Mon, Uroczystość koronacji koronami papieskimi cudownego obrazu Matki Bożej Brzeskiej 30 VI 1996 r., w: Parafia Podwyższenia św. Krzyża, 224005 Brześć - Białoruś (mps-historia parafii i program uroczystości - ADD); G. Rąkowski, Ilustrowany przewodnik po zabytkach kultury na Białorusi, Warszawa 1997, s. 26; Spis kościołów i duchowieństwa diecezji pińskiej w R. P. 1939, Pińsk 1939, s. 65.

${ }^{16}$ ADD, Zespół Archiwum Parafii Brześć, Sygn. XII/V, Nominacja bpa Z. Łozińskiego dla proboszcza ks. Józefa Moniuszki z 2 I 1932 (Num. 46/32), Kanclerz Kurii, ks. kan. Henryk Humnicki do proboszcza ks. Józefa Moniuszki z 8 III 1932 r. (L. 725/32).

${ }^{17}$ ADD, Zespół Archiwum Parafii Brześć, Sygn. XII/V, Upoważnienie biskupa pińskiego dla ks. Józefa Moniuszko z 13 V 1932 (L. 459/R.G.).

${ }^{18}$ Należna za dzierżawę kwota jeszcze pod koniec czerwca 1934 roku nie została uregulowana. Stąd musiała interweniować Kuria Pińska na rzecz Oddziału Drogowego Dyrekcji Kolei Państwowych. ADD, Zespół Parafii Brześć, Sygn. XII/V, Dyrekcja Kolei Państwowych w Wilnie (Oddział Drogowy w Brześciu) do proboszcza na Grajewskim Przedmieściu z 14 VI 1934 (Nr II-26/15), Kuria Pińska do proboszcza na Grajewskim Przedmieściu z 26 VI 1934 (L. 2283/34); Upoważnienie biskupa pińskiego dla ks. Józefa Moniuszko z 13 V 1932 (L. 459/R.G). 
parafia pw. Najświętszego Serca Pana Jezusa, obejmowała część miasta Brześcia Grajewskie Przedmieście oraz osiedls i miejscowości: stacje kolejowe Brześć III, Brześć IV, Brześć V, Adamkowo, Bobrowce, Borowa, Brzozówka, Czernie, Jamno, Katenborg, Klejniki, Kowerdziaki, Kozłowicze, Moszczonka, Piaski, Rzeczyca, Skoki, Stara-Wieś, Szebryń, Szumaki, Terebuń, Tiuchniewicze, Tryszyn, Zadworce. Sąsiednie kościoły parafialne były: Czarnawczyce, Stawy, Zbirohi ${ }^{19}$.

Erygowana parafia nie posiadała beneficjum kościelnego, które winno stanowić podstawę utrzymania proboszcza i wikariuszy erygowanej parafii. Podział kościelnej nieruchomości miejskiej i ziemskiej, pozostających dotąd w użytkowaniu proboszcza kościoła Podwyższenia Świętego Krzyża uznano za niedogodne. Po wysłuchaniu w tym przedmiocie opinii proboszcza parafii Podwyższenia Świętego Krzyża, proboszcza parafii na Grajewce ${ }^{20}$ i Kapituły Katedralnej Pińskiej, biskup zarządził, iż wymienione nieruchomości: miejska i ziemska w mieście Brześciu, będące własnością kościoła rzymskokatolickiego, mają nadal należeć w całości do kościoła parafialnego Podwyższenia Świętego Krzyża. Jednak od bieżącego roku gospodarczego, jedna trzecia część dochodu z folwarku kościelnego, wchodzącego w skład owych nieruchomości, ma stanowić własność każdorazowo proboszcza kościoła pw. Najświętszego Serca Pana Jezusa na Grajewskim Przedmieściu i winna być corocznie mu wypłacona przez proboszcza parafii pw. Podwyższenia Świętego Krzyża ${ }^{21}$.

Dla potrzeb młodej parafii Diecezjalna Rada Gospodarcza poleciła w marcu 1932 roku księdzu dziekanowi i proboszczowi w Kobryniu wypożyczyć ks. kanonikowi Józefowi Moniuszce, dla parafii na Grajewskim Przedmieściu niezbędnych szat liturgicznych z parafii kobryńskiej. Szaty mogły być używane, jednak w takim stanie, by nadawały się do ewentualnej przeróbki ${ }^{22}$.

Sędzia brzeski Wasilewski w imieniu pani Gutowskiej, właścicielki gruntu w Brześciu na Grajewskim Przedmieściu, złożył na początku 1932 roku podanie mieszkańców tegoż przedmieścia o wzięcie pod uwagę oferty pani Gutowskiej, która zdecydowała się ofiarować na budowę świątyni plac o powierzchni pół hektara oraz nieodpłatnie na dwa lata mieszkanie dla księdza oraz salę dla otwarcia tymczasowej kaplicy parafialnej przy ul. Legionów. Kuria biskupia w Pińsku od-

${ }^{19}$ Spis kościołów i duchowieństwa diecezji pińskiej w R. P. 1933 i 1934, Pińsk 1933.

${ }^{20}$ Pytany przez Kurię o opinię ks. Lucjan Żołądkowski z Grajewskiego Przedmieścia o podział beneficjum między dwie parafie: starą i nową (w myśl kanonu 1428 par. 1 KPK), uznał przydzielenie nowej parafii z ówczesnej kościelnej ziemi beneficjalnej w Brześciu pro rata parte $1 / 3$ część. Wobec tego, że wówczas cała ziemia beneficjalna była w dzierżawie, postulował jedną trzecią dochodów $\mathrm{z}$ dzierżawy wypłacać do końca terminu dzierżawy proboszczowi parafii na Grajewce. ADD, Zespół Archiwum Parafii Brześć, Sygn. XII/V, Kuria do ks. L. Żołądkowskiego z 1 X 1935 (L. 3693/35), Odpowiedź ks. Żołądkowskiego do Kurii Pińskiej L. dz. 133/1935.

${ }^{21}$ ADD, Zespół Archiwum Parafii Brześć, Sygn. XII/V, Dekret biskupa pińskiego o podziale beneficjum kościelnego w Brześciu na dwie parafie w tym mieście z 28 VII 1937 (L. 3010/37), Kuria Biskupia (kanonik L. Chwiećko) do proboszcza parafii Najświętszego Serca P. J. w Brześciu z 28 VII 1937 (L. 3010/37 b.).

${ }^{22}$ ADD, Zespół Archiwum Parafii Brześć, Sygn. XII/V, Prezes DRG do dziekana i proboszcza w Kobryniu z 4 III 1932 (L. 267/R.G.). 
kładając czasowo zajęcie stanowiska w tej sprawie, przesłała podanie mieszkańców Grajewskiego Przedmieścia i plan miasta z oznaczeniem proponowanego placu, polecając przechowanie przedstawionej oferty w archiwum nowej parafii ${ }^{23}$.

Jesienią 1932 roku grupa wiernych z parafii pw. Najświętszego Serca Pana Jezusa w Brześciu skierowała do bpa Kazimierza Bukraby petycję o włączenie do utworzonej parafii Najświętszego Serca Pana Jezusa dzielnic: Brześć IV, Brześć III, Brześć I oraz Brześć Centralny. Po rozpatrzeniu petycji, ordynariusz piński polecił kanclerzowi kurii przesłać opinię na temat rezolucji parafian brzeskich. Biskup tłumaczył, że względy moralne i duszpasterskie, na które powołują się autorzy petycji, nie utrudniają wiernym wymienionych dzielnic dostępu do kościoła parafialnego. Ostatecznie podział parafii brzeskich: pw. Podwyższenia Świętego Krzyża i pw. Najświętszego Serca Pana Jezusa miał pozostać jak zostało wyszczególnione $\mathrm{w}$ akcie erekcyjnym ${ }^{24}$.

Plac na planowaną budowę kościoła parafialnego zobowiązał się przekazać parafii zarząd miasta. Biskup piński dnia 26 II 1934 roku przesłał upoważnienie i pełnomocnictwo dla proboszcza na Grajewskim Przedmieściu, mianowanego dnia 13 XII 1933 roku ks. kanonika Lucjana Żołądkowskiego do przyjęcia od zarządu miasta terenu na Grajewce oraz do zawierania w imieniu biskupa wszelkich umów i sporządzania aktów prawnych potrzebnych do przelania tytułu własności wymienionego wyżej placu na rzecz parafii, we wszystkich urzędach, instytucjach sądowych i w wydziale hipotecznym Sądu Okręgowego ${ }^{25}$.

\section{Duszpasterze parafialni}

Do pomocy proboszczowi w pracy pastoralnej w parafii Najświętszego Serca Pana Jezusa ordynariusz piński kierował wikarych. Niektórzy z nich pełnili dodatkowo obowiązki prefekta szkół w Brześciu. W początkowych latach funkcjonowania parafii wikariusze pracowali zazwyczaj przez jeden rok nauki szkolnej. W przypadku zastępstwa pracowali czas krótszy, nawet do miesiąca.

${ }^{23}$ ADD, Zespół Archiwum Parafii Brześć, Sygn. XII/V, Kuria Biskupa do proboszcza parafii Najświętszego Serca Pana Jezusa ks. Józefa Moniuszki z 9 III 1932 (L. 739/32), z 2 IV 1932 (L. 343/R.G.).

${ }^{24}$ ADD, Zespół Archiwum Parafii Brześć, Sygn. XII/V, Kuria Biskupia do ks. kanonika Józefa Moniuszki w Brześciu z 20 IX 1932 (L. 310/32).

${ }^{25}$ Ksiądz Lucjan Żołądkowski został mianowany 13 XII 1933 roku proboszczem na Grajewce oraz wizytatorem nauki religii w szkołach publicznych w Brześciu. ADD, Zespół Archiwum Parafii Brześć, Sygn. XII/V, Dekret biskupa K. Bukraby dla wizytatora ks. Żołądkowskiego z 13 XII 1933 (Num. 5493/33), Pełnomocnictwo biskupa dla ks. L. Żołądkowskiego z 26 II 1934 (L. 774/34). 
Tab. 2. Wikariusze parafii Najświętszego Serca Pana Jezusa w Brześciu.

\begin{tabular}{|l|l|l|}
\hline \multicolumn{1}{|c|}{ Imię i nazwisko } & \multicolumn{1}{c|}{ Weześniej pracowal } & \multicolumn{1}{c|}{ Czas pracy } \\
\hline Franciszek Smorczewski & wikariusz w Drohiczynie & 1 VII 1932 - wikariusz \\
\hline Stanisław Paczkowski & administrator parafii Wsielub & 26 VIII 1932 - 15 VIII 1933 \\
\hline Piotr Guła* & wikariusz w Rudce & $\begin{array}{l}\text { 1 VIII 1933 - 31 III 1934, wikariusz } \\
\text { i prefekt szkół }\end{array}$ \\
\hline Józef Szary & neoprezbiter & 31 III 1934 - 28 IV 1934 \\
\hline Jan Pawlonka & wikariusz w Horodyszczu & 3 VII 1934 - 1935 \\
\hline Stanisław Paczkowski & neoprezbiter & 15 V 1935 - \\
\hline Stanisław Sobótka & neoprezbiter & 16 III 1935 - \\
\hline
\end{tabular}

Źródła: ADD, Zespół Archiwum Parafii Brześć, Sygn. XII/V, Kuria do proboszcza na Grajewskim Przedmieściu z 1 VII 1932 (L. 1999/32), z 27 VIII 1932 (L. 2500/32), z 3 VII 1933 (L. 2572/33); Dekret biskupa do proboszcza z 31 III 1934 (L. 1280/34), z 31 III 1934 (L. 1276/34), z 28 IV 1934 (L. 1687/34); Kuria do ks. Żołądkowskiego z 3 VII 1934 (L. 2533/34), z 2 VIII 1934 (L. 2871/34), z 10 XII 1932 (L. 2045), z 18 VI 1933 (L. 2475/33).

* z diecezji tarnowskiej

Częste zmiany duszpasterzy w młodej parafii, w której organizowano niejako od podstaw i prowadzono posługę pastoralną, zarówno indywidualną jak i w organizowanych grupach parafialnych i stowarzyszeniach religijnych, nie były dla niej sprzyjające. Takie były decyzje pasterza diecezji z którymi, mimo różnych okoliczności, nie można było dyskutować.

\section{Parafialne grupy wiernych}

\section{a) Zgromadzenie III Zakonu św. Franciszka z Asyżü ${ }^{26}$}

We wrześniu 1933 roku Pińska Kuria Diecezjalna z polecenia biskupa skierowała do proboszczów diecezji kwestionariusz na temat organizacji III Zakonu św. Franciszka w parafii oraz jego zarządu. Wypełnioną ankietę należało odesłać do kurii w przeciągu dwóch tygodni.

${ }^{26}$ III Zakon franciszkański - inaczej tercjarze św. Franciszka. To grupy zakonów i zgromadzeń męskich i żeńskich oraz franciszkańskiego zakonu świeckich, który mimo nazwy zakonu posiada charakter międzynarodowego stowarzyszenia publicznego. Pochodzą od założonych pod wpływem św. Franciszka z Asyżu (1182-1226) Braci i Sióstr od pokuty - grupy ludzi świeckich pragnących realizować ideały życia franciszkańskiego. Kryterium przynależności danego instytutu życia konsekrowanego do III Zakonu jest jego afiliacja. Z czasem w łonie ruchu niektóre grupy tercjarzy przyjmowały zorganizowaną formę życia wspólnego, tworząc zakony, zwane trzecim zakonem regularnym, którego pierwszą Regułę zatwierdził Leon X w 1521 roku. Po pierwszej wojnie światowej tercjarze świeccy osiągnęli apogeum liczebności - 4 mln członków w 24 tysiącach wspólnot. Obecnie jest to ok. 500 tysięcy osób. Męski Trzeci Zakon Regularny liczy ok. 800 braci, zaś kongregacje żeńskie - ok. 1.300 sióstr. III Zakon posiada liczne przywileje: 1) zwolnienie członków z feudalnej przysięgi wierności, a więc i ze służby wojskowej, 2) wyjęcie spod sądownictwa cywilnego jako osób poświęconych Bogu, 3) wyjęcie spod interdyktów nakładanych na całe miasta. Strojem tercjarzy był szkaplerz, określony w 1508 roku przez pap. Juliusza II, który zastępował noszenie habitu. Klemens XI w 1704 roku zatwierdził mały Szkaplerz św. Franciszka z Asyżu (szkaplerz franciszkański tzw.seraficki) na tasiemkach, noszony pod ubraniem. W 1957 roku wprowadzono Medalik św. Franciszka z Asyżu i pozwolono na zastępowanie nim szkaplerza. Aktualnie noszony jest drewniany krzyżyk Tau, zawieszony na sznurku lub rzemyku z trzema węzełkami, jako symbolu franciszkańskiej pokuty. Z grona tercjarzy pochodzili święci, m.in. Elżbieta Węgierska, Ludwik IX. Do III Zakonu należeli założycielie zakonów, m.in.: Brygida Szwedzka, Ignacy Loyola, Filip Neri, Aniela Merici. T. Wytrwał, Zakony trzecie, w: EK, t. 20, Lublin 2014, kol. 1196-1197. 
Z sporządzonej przez proboszcza ankiety dowiadujemy się, że III Zakon św. Franciszka założony został w parafii Najświętszego Serca Jezusowego w kwietniu 1932 roku. Z tej okazji jego członkowie odprawili wspólne rekolekcje. Jego dyrektorem został ks. kanonik Józef Moniuszko. Początki były skromne. Do III Zakonu należało dwóch braci, dwóch profesów i dwóch nowicjuszów oraz trzy siostry-nowicjuszki. Zebrania tercjarskie odbywali co miesiąc, uiszczając przy tej okazji składkę miesięczną w wysokości 50 groszy. Uczestniczyli wówczas we wspólnym nabożeństwie z parafianami. Tercjarze nie posiadali własnej rady, a członkami kierowała zelatorka. Na początek członkowie nie mieli powierzonych specjalnych zadań w parafii, np. opieka nad chorymi ${ }^{27}$.

W myśl kanonu 686 par. 3 Kodeksu Prawa Kanonicznego biskup piński Kazimierz Bukraba w kwietniu 1934 roku erygował Zgromadzenie III-go Zakonu św. Franciszka z Asyżu w parafii Najświętszego Serca Pana Jezusa w Brześciu²8.

\section{b) Bractwo Straży Honorowej Najświętszego Serca Pana Jezusa ${ }^{29}$}

Dnia 2 XI 1933 roku proboszcz kościoła Najświętszego Serca Jezusowego skierował do Pińskiej Kurii Biskupiej podanie o pozwolenie na założenie Bractwa Straży Honorowej Najświętszego Serca Pana Jezusa oraz agregacji do Krakowskiego Arcybractwa przy kościele sióstr wizytek w Krakowie. Biskup piński bio-

${ }^{27}$ ADD, Zespół Archiwum Parafii Brześć, Sygn. XII/V, Okólnik Kurii do proboszczów diecezji z 22 IX 1933 (L. 3992/33), Kwestionariusz w sprawie tercjarskiej, podpisany przez ks. L. Żołądkowskiego.

${ }^{28}$ ADD, Zespół Archiwum Parafii Brześć, Sygn. XII/V, Biskup piński do proboszcza parafii na Grajewskim Przedmieściu z 12 IV 1934 (L. 1328/34).

${ }^{29}$ Straż Honorowa Najświętszego Serca Pana Jezusa - inspiratorką Straży Honorowej NSPJ była zakonnica, urodzona w Besancon we Francji w 1825 roku - Konstancja Bernard z klasztoru Nawiedzenia Najświętszej Marii Panny (sióstr wizytek) - siostra Marii od Najświętszego Serca Pana Jezusa. Dnia 13 III 1863 roku zaproponowała ona siostrom wizytkom, potem innym zgromadzeniom zakonnym, a także wiernym aby zapisywali się do stowarzyszenia, które 9 III 1864 roku zostało zatwierdzone jako Bractwo, a 26 XI 1878 roku Arcybractwo Straży Honorowej Najświętszego Serca Pana Jezusa. Ze swojego osobistego nabożeństwa do Najświętszego Serca Pana Jezusa siostra Maria zaczerpnęła myśl, aby każdy jego członek codziennie odprawiał jedną godzinę „,straży”. W czasie tej godziny nic nie zmieniając ze swoich codziennych obowiązków, winien łączyć się myślą z ofiarą Pana Jezusa na krzyżu dla zbawienia świata. Wybrana godzina czuwania była zapisana na tzw. ,zegarze” i w ten sposób tworzono wieniec czcicieli z całego świata, czuwających przy Panu Jezusie na wzór Najświętszej Marii Panny, św. Marii Magdaleny i św. Jana. W rok po założeniu Straż Honorowa uzyskała aprobatę Papieża Piusa IX, który nazwał się pierwszym członkiem Straży Honorowej. W Polsce Bractwo Straży Honorowej zostało kanonicznie założone w 1869 roku przez biskupa Antoniego Gałeckiego przy kościele sióstr wizytek w Krakowie, podniesione do Arcybractwa przez nuncjusza Achillesa Rattiego w 1919 roku. Z okazji 100-lecia założenia Straży Honorowej we Francji wprowadzono drugą jej nazwę „Godzina Straży”. Po Soborze Watykańskim II zaproponowano nową nazwę „Godzina Obecności przy Sercu Jezusa” z zachowaniem trzech istotnych elementów Arcybractwa: kult Serca Pana Jezusa, kierunek wynagradzający i eucharystyczny, uświęcenie obowiązków stanu. Ta zmiana uzyskała aprobatę Rady Papieskiej ds. Laikatu w 1973 roku, a 10 XII 1976 roku zaaprobowano Stowarzyszenie „Godzina Obecności przy Sercu Pana Jezusa” oraz jego statut. Praktyki religijne odprawiane przez członków Stowarzyszenia nie obowiązują pod grzechem. E. Ziemann, Serce Jezusa, w: EK, t. 18 Lublin 2013, kol. 13. 
rąc pod uwagę fakt, że istnienie bractwa może stać się źródłem błogosławieństwa i łask Bożych dla wiernych należących do parafii Najświętszego Serca Pana Jezusa, a przez to przyczyni się do większej chwały Bożej i zbawienia dusz, powołał dnia 4 V 1934 roku uroczystym aktem Straż Honorową Najświętszego Serca Pana Jezusa w parafii przy kościele Najświętszego Serca Pana Jezusa, zezwalając proboszczowi parafii na połączenie bractwa parafialnego z Arcybractwem Straży Honorowej Najświętszego Serca Pana Jezusa w Krakowie, aby członkowie mogli w pełni brać udział w odpustach i łaskach duchownych, nadanych Arcybractwu Krakowskiemu. Ks. Lucjan Żołądkowski i jego następcy zostali mianowani dyrektorami bractwa parafialnego z prawem wyznaczania zastępców. Przyjmowanych do bractwa parafialnego członków należało zapisywać w księdze konfraterni z zaznaczeniem w niej decyzji biskupa o przyjęciu ${ }^{30}$.

\section{c) Stowarzyszenie „Dzieci Maryi" ${ }^{31}$}

Na prośbę proboszcza parafii Najświętszego Serca Pana Jezusa na Grajewskim Przedmieściu w Brześciu z dnia 16 IX 1935 roku ordynariusz piński erygował Stowarzyszenie „Dzieci Maryi” pw. Najświętszej Maryi Panny Niepokalanego Poczęcia pod patronatem błog. Andrzeja Boboli ${ }^{32}$.

${ }^{30}$ ADD, Zespół Archiwum Parafii Brześć, Sygn. XII/V, Ks. L. Żołądkowski do biskupa pińskiego z 2 XI 1933 (L. 349); Zezwolenie biskupa na założenie Bractwa na Grajewskim Przedmieściu z 21 II 1934 (L. 253/34), podpisany kanclerz Kurii ks. Bronisław Kiełbasa; Sprawozdanie do Kurii Biskupiej z 29 IV 1935 (L. dz. 65) z przeżytego Roku Jubileuszowego 1934.

${ }^{31}$ Stowarzyszenie „Dzieci Maryi” - obejmuje Dzieci Maryi i Młodzież Maryjną, młode dziewczęta i chłopców, którzy chcą żyć duchem maryjnym i szerzyć cześć Najświętszej Maryi Panny Niepokalanej. Powstało ono pod wpływem objawień Matki Bożej św. Katarzynie Laboure w 1830 roku w Paryżu. Zostało zatwierdzone przez papieża Piusa IX dnia 20 czerwca 1847 roku. W Polsce Stowarzyszenie działa od 1852 roku. W okresie powojennym oficjalnie zostało rozwiązane jednak w miarę istniejących możliwości rozwijało swoją działalność. Stowarzyszenie Dzieci i Młodzieży Maryi osiąga swój cel poprzez: uczestnictwo we mszy świętej, naśladowanie NMP, rozpowszechnianie i noszenie Cudownego Medalika zgodnie z obietnicą zawartą w słowach Maryi: „Wszyscy, którzy nosić go będą otrzymają wiele łask”. Hasłem Stowarzyszenia są słowa: „O Maryjo bez grzechu poczęta, módl się za nami, którzy się do Ciebie uciekamy”. Dzieci Maryi idąc za wezwaniem Matki Bożej wypowiadają tę modlitwę jak najczęściej. Zawołaniem Dzieci Maryi są słowa: „Cześć Maryi”, odpowiedź: „Cześć Niepokalanej”. K. Kuźmak, Dzieci Maryi, w: EK, t. 4, Lublin 1985, kol. 465-469.

${ }^{32}$ Bobola Andrzej (1591-1657) - pochodził z rodziny szlacheckiej. W 1611 roku wstąpił w Wilnie do jezuitów. Tam studiował filozofię i teologię. W 1622 roku przyjął święcenia kapłańskie. Pracował w Nieświeżu, Wilnie, Bobrujsku jako superior, w Płocku jako kaznodzieja i prefekt szkół jezuickich, w Łomży, w Pińsku. Jako utalentowany kaznodzieja, spowiednik i duszpasterz, już za życia nazywany był apostołem Pińszczyzny gdyż nawrócił na katolicyzm wielu prawosławnych. Jego działność spowodowała u prawosławnych wzrost nienawiści do niego oraz jezuitów, uważanych za twórców unii brzeskiej z 1596 roku. A. Bobola poniósł śmierć męczeńską w maju 1657 r. na rynku Janowa Podlaskiego z rąk Kozaków, którzy napadli na miasto, dokunujavc rzezi mieszkańców. Jego ciało spoczęło w Pińsku, Połocku, Moskwie, Rzymie. Po kanonizacji Andrzeja Boboli w Rzymie dnia 17 IV 1938 roku, od czerwca tego roku jego doczesne szczątki spoczęły w Warszawie. B. Natoński, Andrzej Bobola, w: EK, t. 1, Lublin 1985, kol. 534-535. 
Dyrektorem Stowarzyszenia został mianowany proboszcz parafii i jego prawni następcy ${ }^{33}$.

\section{d) Papieskie Dzieła Rozkrzewiania Wiary ${ }^{34}$}

Na początku grudnia 1934 roku dyrektor Papieskiego Dzieła Rozkrzewiania Wiary na diecezję pińską z siedzibą w seminarium duchownym - ks. Michał Krzywicki ${ }^{35}$, przesłał do księży proboszczów blankiety sprawozdawcze z podaniem danych o parafialnych Papieskich Dziełach Rozkrzewiania Wiary. Grupa sympatyków misji w parafii Najświętszego Serca Pana Jezusa zawiązała się na początku 1934 roku. Nie znamy ilości członków w początkowym okresie, jednak w ciągu tego roku zdołała zgromadzić pokaźną sumę na misje w kwocie 90.33 złote. W tym ze składek członkowskich 31.50 złotych, ze składek w uroczystość Trzech Króli kwotę 22.28 złotych oraz w niedzielę misyjną kwotę 36.55 złotych. Według sporządzonego sprawozdania za rok $1935 \mathrm{w}$ parafii grupa misyjna liczyła 10 członków. Nie posiadała formalnego i czynnego zarządu. Zebrania odbywały się dwukrotnie w ciągu roku: w niedzielę misyjną i w uroczystość Trzech Króli. Wtedy członkowie i sympatycy misji uczestniczyli we mszy świętej z kazaniem o tematyce misyjnej oraz zaprezentowali dwa odczyty o tematyce misyjnej Kościoła. Dyrektor parafialny dzieł misyjnych i proboszcz stwierdzał, że zainteresowanie dla spraw misyjnych w parafii rozwijał się m.in. z powodu niedawnej erekcji

${ }^{33}$ ADD, Zespół Archiwum Parafii Brześć, Sygn. XII/V, Biskup piński K. Bukraba do proboszcza Żołądkowskiego z 21 IX 1935 r. (L. 3328/1935), podpisany kanclerz Kurii ks. Bronisław Kiełbasa.

${ }^{34}$ Papieskie Dzieła Rozkrzewiania Wiary (PDRW) - obok Papieskiego Dzieła św. Piotra Apostoła (od 1889), Papieskiego Dzieła Misyjnego Dzieci (od 1843) oraz Papieskiej Unii Misyjnej (od 1916) działają w ramach Papieskich Dzieł Misyjnych, założonych w XIX i XX wieku, w celu budzenia świadomości misyjnej wśród wiernych Kościoła katolickiego. Ich zadaniem jest wspieranie działalności misyjnej w Kościele katolickim na całym świecie, w ponad 150 krajach świata. Głównymi celami PDRW są: kształtowanie odpowiedzialności za misje, duchowa i materialna pomoc misjom, informowanie o wielorakich potrzebach misji, kształtowanie animatorów i współpracowników misji. R. Dziura, Papieskie Dzieła, w: EK, t. 14, Lublin 2010, kol. 1280-1281.

${ }^{35}$ Ks. Krzywicki Michał (1895-1967) - kapłan diecezji pińskiej, infułat, administrator apostolski diecezji pińskiej w Drohiczynie nad Bugiem. Urodził się w Rakowie k. Mińska. W latach 19121917 odbył studia seminaryjne w Petersburgu. Święcenia kapłańskie przyjął w 1919 roku w Wołczkiewiczach. Studia specjalistyczne podjął na KUL, gdzie uzyskał w 1927 roku doktorat z teologii. Pracował jako wykładowca w seminarium w Pińsku, nauczyciel religii w szkołach powszechnych miasta (do 1931), moderator Sodalicji Mariańskiej Uczennic w Pińsku i był skarbnikiem Papieskiego Dzieł Rozkrzewiania Wiary. W 1939 roku został wraz z alumnami pińskimi aresztowany przez sowietów. Po uwolnieniu wyjechał do Wilna, a w 1945 roku do Białegostoku. Tu podjął wykłady w seminarium duchownym i obowiązki sędziego prosynodalnego. Od 1950 roku ks. infułat Michał Krzywicki zarządzał jako administrator apostolski rezydujący w Drohiczynie, terenem diecezji pińskiej pozostającej w granicach PRL. Na określenie tego terytorium celowo używano określenia Diecezja w Drohiczynie n. Bugiem a unikano nazwy Diecezja pińska. Siedzibę kurii przeniósł z Bielska Podlaskiego do Drohiczyna. Tu reaktywował wyższe seminarium duchowne, początkowo połączone z seminarium w Siedlcach, a od 1957 roku jako samodzielne. W 1962 roku został prepozytem pińskiej kapituły katedralnej z tytułem infułata. E. Ozorowski, Krzywicki Michał, w: EK, t. 10, Lublin 2004, kol. 8-9. 
parafii, a dodatkowo pewna liczba parafian należała już w macierzystej parafii do bractw i stowarzyszeń religijnych. Stan składek członkowskich w grudniu 1935 roku wynosił kwotę 32.20 złotych. Ofiary składane w puszkach kartonowych na katechistów wynosiły 19.70 złotych, w sumie 51.96 złotych. Podane kwoty należało przesłać przekazem pocztowym na konto czekowe w Pocztowej Kasie Oszczędności dla Papieskiego Dzieła Rozkrzewiania Wiary w Pińsku - konto czekowe Nr 81614. Sympatycy misji korzystali z biblioteki parafialnej, w tym z biuletynu „Misje Katolickie"36.

\section{e) Rok Jubileuszowy w Kościele powszechnym w 1934 roku}

Ze względu na kończący się Rok Jubileuszowy 1934 w Kościele powszechnym i konieczność przesłania Stolicy Apostolskiej dokładnego sprawozdania z obchodu Jubileuszu w diecezji pińskiej, Pińska Kuria Diecezjalna poleciła dnia 5 IV 1935 roku proboszczom, rektorom i prefektom szkół, po zakończeniu w dniu 28 kwietnia tego roku uroczystości jubileuszowych, sporządzenie sprawozdania z przebiegu tychże uroczystości w parafiach, kaplicach publicznych i szkołach. W ciągu Roku Jubileuszowego w parafii grajewskiej odprawiono trzy procesje jubileuszowe w których uczestniczyło po kilkaset osób w każdej. Wierni odbywali prywatnie praktyki jubileuszowe korzystając z wydanych specjalnie „Jubileuszówek". W sali parafialnej zorganizowano odczyty o Męce Pańskiej, dla łącznej liczby uczestników do 300 osób. Na pamiątkę Roku Jubileuszowego poświęcono specjalnie sporządzony krzyż. W trakcie przeżywania Roku Jubileuszowego biskup ordynariusz erygował w kwietniu 1934 roku w kościele parafialnym stacje Drogi Krzyżowej oraz Straż Honorową Najświętszego Serca Jezusowego. Na zakończenie Jubileuszu Odkupienia odprawiono w parafii liturgiczne nabożeństwa w czasie triduum przy licznym udziale wiernych ${ }^{37}$.

\section{f) Parafialne święta odpustowe}

Proboszcz na Grajewskim Przedmieściu skierował dnia 4 XII 1932 prośbę do Pińskiej Kurii Biskupiej o zatwierdzenie proponowanych przez niego świąt

36 „Misje Katolickie” - miesięcznik popularnonaukowy wydawany od 1882 roku przez jezuitów w Krakowie, a od 1936 roku w Warszawie (do 1939). Założycielem czasopisma był o. Henryk Jackowski, prowincjał jezuitów w Galicji. Stałym korespondentem był abp Władysław Michał Bonifacy Zaleski (1852-1925 - patriarcha Antiochii, dyplomata w służbie Stolicy Apostolskiej, podróżnik i przyrodnik). Pismo stało na wysokim poziomie edytorskim, bogato ilustrowane. Na jego łamach ukazywały się m.in. opisy prac misjonarskich w różnych rejonach świata, wiadomości z terenów misyjnych, a także listy misjonarzy. Nakład sięgał nawet 3.000 egzemplarzy. R. Dziura, „Misje Katolickie”, w: EK, t. 12, Lublin 2008, kol. 1220.

Za rok sprawozdawczy 1936 przesłano kwotę 60 złotych: 41 złotych ze składek członkowskich i 19 złotych ofiary z puszek na katechistów. ADD, Zespół Archiwum Parafii Brześć, „Varia” 19311935, Dyrektor diecezjalny Papieskich Dzieł Misyjnych do proboszczów z 26 XI 1934 (L. 65); Sprawozdania roczne: 1935, 1936 z parafii Najświętszego Serca Pana Jezusa Papieskiego Dzieła Rozkrzewiania Wiary.

${ }^{37}$ ADD, Zespół Archiwum Parafii Brześć, Sygn. XII/V, Kuria Diecezjalna Pińska do proboszczów, rektorów i prefektów szkół z 5 V 1935 (L. 1130/35); Sprawozdanie z obchodu Roku Jubileuszowego z 29 IV 1935 (L. dz. 65). 
odpustowych w parafii aby wierni z okazji ich przeżywania mieli możliwość uzyskania odpustu zupełnego. W odpowiedzi kanclerz kurii poinformował, że prośba proboszcza zostanie przesłana do odpowiedniej kongregacji przy Stolicy Apostolskiej. Jednak sprawa ta przez najbliższych pięć lat nie została definitywnie załatwiona, nie wiadomo z jakich powodów. Do sprawy powrócono w późniejszych latach $^{38}$.

Piński „Przegląd Diecezjalny” podawał kilkakrotnie na swych łamach wezwanie, które było także kierowane pisemnie przez kurię do księży dziekanów, aby proboszczowie nadesłali do kurii dawne reskrypty papieskie na prawo uzyskiwania w poszczególnych parafiach odpustów zupełnych. Wobec konieczności załatwienia tej sprawy dla każdej parafii, kuria wezwała w marcu 1937 roku wszystkich proboszczów, aby w ciągu dwóch tygodni nadesłali do kurii dotychczasowe reskrypty papieskie, nadające władzę otrzymania odpustów zupełnych w danej parafii. Jeżeli parafia takowego nie posiadała, proboszcz winien podać datę, kiedy taki odpust należało ustanowić w jego parafii dla dobra duchowego wiernych. W odpowiedzi na takie pismo proboszcz kościoła parafialnego na Grajewskim Przedmieściu poinformował Pińską Kurię Biskupią, że tamtejsza parafia żadnych odpustów nie posiada. W związku z powyższym proponował święta z możliwością uzyskania odpustu zupełnego przez wiernych, a mianowicie w uroczystość Najświętszego Serca Jezusowego, po oktawie Bożego Ciała (tytuł kościoła) oraz na uroczystość Narodzenia Najświętszej Maryi Panny - 8 kwietnia ${ }^{39}$.

\section{g) Parafialna Rada Gospodarcza}

Stosownie do kanonu 1183 Kodeksu Prawa Kanonicznego, w każdej parafii winny być ukonstytuowane Parafialne Rady Gospodarcze. W związku z tym ordynariusz piński przesłał do księży proboszczów rezolucję w tej sprawie. Sprawa była ważna $\mathrm{z}$ uwagi na mającą wejść $\mathrm{w}$ życie ustawę o świadczeniach na rzecz Kościoła. Przedstawieni do zatwierdzenia kandydaci mieli być odpowiednio przez księży proboszczów wybrani, jako ludzie zaufania zarówno proboszcza jak i parafian, aby w ten sposób mogli być pomocni proboszczowi, a nie stwarzali przeszkód w administrowaniu dobrem kościelnym. Listę sześciu kandydatów z parafii należało przesłać do Pińskiej Kurii Biskupiej do dnia 10 I 1934 roku, z których trzech miało być zatwierdzonymi jako członkowie rady, pozostali jako zastępcy ${ }^{40}$.

Z przedstawionych przez proboszcza ks. Lucjana Żołądkowskiego kandydatów do Parafialnej Rady Gospodarczej ordynariusz zamianował w kwietniu 1934 roku następujące osoby: Aleksandra Rodziewicza, Władysława Judyckiego i An-

${ }^{38}$ ADD, Zespół Archiwum Parafii Brześć, Sygn. XII/V, Kuria Biskupia do proboszcza parafii na Grajewskim Przedmieściu z 13 XII 1932 (L. 2047/32).

${ }^{39}$ ADD, Zespół Archiwum Parafii Brześć, Sygn. XII/V, Kuria Biskupia do proboszcza Najświętszego Serca P. J. z 1 III 1937 (L. 895/37), Proboszcz brzeski do Kurii Pińskiej 1937 rok.

${ }^{40}$ Przedstawieni kandydaci winni posiadać następujące przymioty: 1) być wierzącymi i praktykującymi katolikami, 2) cieszyć się dobrą opinią i sympatią swoich parafian, 3) odznaczać się gospodarnością i solidnością w prowadzeniu swych interesów własnych. ADD, Zespół Archiwum Parafii Brześć, Sygn. XII/V, Okólnik biskupa pińskiego do proboszczów diecezji pińskiej z 19 XII 1933 (L. 5678/33). 
toniego Jurskiego. Jako zastępcę mianowany został Franciszek Niedźwiecki. Z tych członków rady ksiądz proboszcz miał rozdzielić funkcje sekretarza i skarbnika Ich kompetencje, poza ogólnymi wskazaniami prawa kanonicznego miała określić w najbliższej przyszłości instrukcja zatwierdzona przez ordynariusza ${ }^{41}$.

\section{Jubileusz ordynariusza}

Młoda parafia włączyła się w przygotowywanie obchodu 25-lecia kapłaństwa Jego Ekscelencji biskupa pińskiego Kazimierza Bukraby, przypadający na dzień 2 II 1934 roku. Informując o tej rocznicy duchowieństwo i wiernych kresowej diecezji pińskiej, powołany komitet organizacyjny ${ }^{42} \mathrm{w}$ swojej odezwie skierował apel, by według nakreślonych wskazań przyczynić się do jak najstosowniejszego uczczenia Jubilata. $Z$ tej okazji podano także okoliczności przemawiające za zorganizowaniem jubileuszu mającego wydźwięk nie tylko osobisty dla hierarchy kościelnego, ale także by oddać publiczny i zbiorowy hołd zasługom obywatelskim, kapłańskim i biskupim Jubilata oraz by dać możność Akcji Katolickiej wskazania łączności jaka istnieje między biskupem diecezji a wiernymi, a przez biskupa ze Stolicą Świętą. Uczczenie biskupa, przez uroczysty obchód 25-lecia jego pracy kapłańskiej miał być także okazją do ukazania i podkreślenia miłości do Stolicy Świętej i wykazaniem łączności i jedności Kościoła katolickiego na Kresach Wschodnich Rzeczypospolitej z biskupem Rzymu - papieżem. Uczczenie publiczne Biskupa katolickiego, a w nim jednocześnie wysokie wartości obywatela Polaka, miało podnieść znaczenie państwowe działalności Kościoła katolickiego, który broniąc odwiecznych praw Bożych, bronił najskuteczniej interesów państwa. Wreszcie organizowane obchody jubileuszowe miały podkreślić i zaakcentować najpotężniejszy czynnik ładu i porządku społecznego, jakim był Kościół katolicki43.

W obchody jubileuszowe była zaangażowana każda parafia diecezji. Dnia 2 II 1934 roku winno być odprawione w każdej parafii uroczyste nabożeństwo z udziałem jak najliczniejszych wiernych. Winna być przygotowana okolicznościowa akademia, z podjęciem ważnych i aktualnych tematów, które zostały przesłane do poszczególnych komitetów parafialnych przez diecezjalny komitet organizacyjny. Wszyscy członkowie stowarzyszeń religijnych i społecznych winni złożyć swój podpis pod zbiorowym adresem, który miał być wysłany do Jubilata. Postulowana była także zbiórka pieniężna z przeznaczeniem jej na dar dla Jubilata.

${ }^{41}$ ADD, Zespół Archiwum Parafii Brześć, Sygn. XII/V, Wikariusz generalny bp Karol Niemira do proboszcza ks. L. Żołądkowskiego z 27 IV 1934 (L. 1497/34).

${ }^{42}$ Za Komitet Organizacyjny podpisali się: ks. biskup dr Karol Niemira, ks. Henryk Humnicki - prałat-prepozyt, ks. Wincenty Giebartowski - kanonik Kapituły, ks. Bronisław Kiełbasa - kanonik Kapituły. Do reprezentacyjnego Komitetu Głównego weszły osoby zaproszone i delegowane przez poszczególne parafie. ADD, Zespół Archiwum Parafii Brześć, Sygn. XII/V, Odezwa Komitetu Organizacyjnego Obchodu 25-lecia kapłaństwa J. E. księdza Kazimierza Bukraby biskupa pińskiego, Pińsk, w listopadzie 1933 roku, s. 1-2.

${ }^{43}$ ADD, Zespół Archiwum Parafii Brześć, Sygn. XII/V, Odezwa Komitetu Organizacyjnego Obchodu 25-lecia kapłaństwa J. E. księdza Kazimierza Bukraby biskupa pińskiego, Pińsk, w listopadzie 1933 roku, s. 1. 
Zarówno zbiorowy adres jak i zbiórka pieniężna winny być przesłane na adres biskupa sufragana pińskiego Karola Niemira ${ }^{44}$ w Pińsku (ul. Kościuszki 16, seminarium), do dnia 15 I 1934 roku.

W przesłanej na początku września 1935 roku instrukcji do jesiennej wizytacji kanonicznej biskupa w diecezji pińskiej, duszpasterze parafialni winni zorganizować zarówno przybycie biskupa do danej parafii, przebieg nabożeństw liturgicznych, dokumentację parafialną, sprawozdania i dane statystyczne dotyczące parafii wizytowanej do sporządzenia protokołu wizytacyjnego. Instrukcja przewidywała aby wizytacji towarzyszyli duchowni okolicznych parafii. Zgodnie z rytuałem wizytacji proboszcz parafii oddawał klucze świątyni na czas wizytacji biskupowi. Na rozpoczęcie wizytacji proboszcz przedstawiał stan moralny i materialny wiernych parafii, ze wskazaniem parafian szczególnie angażujących się W życie parafii. W trakcie wizytacji organizowana była spowiedź i komunią święta, a biskup udzielał sakramentu bierzmowania. W czasie wizytacji odprawiana była procesja za zmarłych. Pasterz diecezji odbywał spotkanie z miejscowymi nauczycielami oraz przeprowadzał egzaminowanie katechizmowe uczniów przystępujących do bierzmowania. Wreszcie następowało wizytowanie cmentarza parafialnego, zabudowań gospodarczych, kancelarii parafialnej, działalności Akcji Katolickiej, stowarzyszeń i bractw religijnych działających $w$ parafii ${ }^{45}$. W niedzielę poprzedzającą wizytację proboszcz winien wyjaśnić $\mathrm{z}$ ambony parafianom cel, znaczenie wizytacji i korzyści jakie winny z wizytacji wyniknąć. Niestety nie dysponujemy danymi archiwalnymi dotyczącymi przeprowadzonej pierwszej wizytacji kanonicznej w erygowanej parafii na Grajewce.

Słowa kluczowe: Brześć nad Bugiem, historia Kościoła na Kresach Wschodnich, parafia rzymskokatolicka w Brześciu nad Bugiem

${ }^{44}$ Bp Niemira Karol urodził się w 28 X 1882 roku w Warszawie. Osierocony w wieku dwóch lat, wychowywany był przez siostry zakonne. W latach 1904-1909 studiował w Metropolitalnym Seminarium Duchownym w Warszawie. Jako wybitnie zdolny, skierowany został na Gregorianum do Rzymu, gdzie uzyskał tytuł doktora prawa kanonicznego. Święcenia kapłańskie przyjął w 1911 roku w Warszawie. Pracował jako wikariusz w Łodzi, a od 1912 roku w Warszawie, od 1919 roku był kapelanem Wojska Polskiego, od 1920 roku był proboszczem archikatedry warszawskiej, a od 1925 roku wizytatorem religii w warszawskich szkołach zawodowych. Jako proboszcz parafii św. Augustyna angażował się w prace społeczne i charytatywne w Warszawskim Towarzystwie Dobroczynności i charytatywnym Komitecie Obywatelskim oraz był radnym miasta Warszawy. W 1933 roku mianowany został sufraganem diecezji pińskiej. Wkrótce po konsekracji został mianowany wikariuszem generalnym diecezji pińskiej, a od 17 VIII 1933 roku rektorem seminarium diecezjalnego w Pińsku i asystentem kościelnym Diecezjalnego Instytutu Akcji Katolickiej. Po objęciu rządów przez wikariusza kapitulnego - ks. Henryka Humnickiego rządy w diecezji pińskiej pozostającej w granicach Polski - w Drohiczynie nad Bugiem, biskup Niemira osiadł w Warszawie. W maju 1945 roku podjął próbę zorganizowania kurii diecezjalnej w Bielsku Podlaskim. Pod koniec życia rezydował w Czubinie koło Błonia, pełniąc posługę biskupią, głównie na Ziemiach Odzyskanych. Zmarł 8 VII 1965 roku w Czubinie. Z. Rostkowski, Niemira Karol, w: EK t. 13 Lublin 2009, kol. 1138-1139.

${ }^{45}$ ADD, Zespół Archiwum Parafii Brześć, Sygn. XII/V, Wikariusz generalny bp Karol Niemira do proboszcza parafii Najświętszego Serca Pana Jezusa z 3 IX 1935 (L. 3005/35). 


\section{BIBLIOGRAFIA}

\section{I. Źródła archiwalne}

Archiwum Diecezjalne w Drohiczynie - ADD

Zespół Archiwum Parafii Baranowicze: Sygnatura XII/V

Zespół: Archiwum Parafii Brześć: Sygnatura XI/Mon

\section{II. Źródła drukowane}

Bieszanow W., Twierdza Brzeska, Warszawa 2012.

Dziura R., ,"Misje Katolickie”, w: Encyklopedia Katolicka, t. 12, Lublin 2008, kol. 1220.

Dziura R., Papieskie Dzieła, w: Encyklopedia Katolicka, t. 14, Lublin 2010, kol. 12801281.

Kumor B., Granice metropolii i diecezji polskich (968-1939) cd., „Archiwa Biblioteki i Muzea Kościelne", 22 (1971) s. 319-402.

Kuźmak K., Dzieci Maryi, w: Encyklopedia Katolicka, t. 4, Lublin 1985, kol. 465-469

Mihailik L., Kościół katolicki na Grodzieńszczyźnie 1939-1956, Warszawa 2008.

Misiurek J., Łoziński Zygmunt, w: Encyklopedia Katolicka, t. 11, Lublin 2006, kol. 554555.

Petrani A., Bukraba Kazimierz, w: Encyklopedia Katolicka, t. 2 Lublin 1985, kol. 11891190.

Rąkowski G., Ilustrowany przewodnik po zabytkach kultury na Białorusi, Warszawa 1997. Rostkowski Z., Niemira Karol, w: Encyklopedia Katolicka t. 13 Lublin 2009, kol. 11381139.

Spis kościołów i duchowieństwa diecezji pińskiej w R. P. 1933 i 1934, Pińsk 1933.

Spis kościołów i duchowieństwa diecezji pińskiej w R. P. 1935, Pińsk 1935.

Spis Kościołów i Duchowieństwa Diecezji Pińskiej, Pińsk 1936.

Spis kościołów i duchowieństwa diecezji pińskiej w R. P. 1935, Pińsk 1937, s. 18-23.

Spis kościołów i duchowieństwa diecezji pińskiej w R. P. 1939, Pińsk 1939.

Wojciechowski K., Cmentarz katolicki w Brześciu, „Niedziela” nr 45 (737) z 4 XI 2012, s. 7.

Wytrwał T., Zakony trzecie, w: Encyklopedia Katolicka, t. 20, Lublin 2014, kol. 11961197.

Ziemann E., Serce Jezusa, w: Encyklopedia Katolicka, t. 18, Lublin 2013, kol. 7-27. 


\title{
THE ORIGINS OF THE PARISH OF THE SACRED HEART OF JESUS IN BREST IN THE SUBURB OF GRAJEWO
}

\begin{abstract}
Summary
The Polish city of Brest on the Bug (the Eastern borderlands), developing after World War I, needed another Roman Catholic Church for the local faithful. Granting the requests of the faithful, the bishop of Pińsk Zygmunt Łoziński canonically erected - on 2 January 1932- the Parish of the Sacred Heart of Jesus, which was the second parish in Brest, with the Parish of Elevation of the Holy Cross being the first one. Rev. Józef Moniuszko was the first parish priest and its organizer. The bishop sent one vicar to help him in parish work. Soon some parish groups of the faithful were organized: the Third Order of St. Francis of Assisi, the Pontifical Society for the Propagation of the Faith, Brotherhood of the Guard of Honour of the Sacred Heart of Jesus, the Association of "Mary's Children". All of those groups intensified the religious life of the parish.
\end{abstract}

Keywords: Brest on the Bug, the history of the Church in the Polish Eastern Borderlands, Roman Catholic parishes in Brest on the Bug 